\title{
Review on Mega-trends in shipping and port \& its implications
}

\author{
Hyun-Duk Kim* · Ki-Myoung Ahan** \\ *Full-time Lecturer, Dept. of Distribution Management, Tongmyong University of Information Technology, Pusan 608-711, Korea \\ **Professor, Division of Shipping Management, Korea Maritime University, Pusan 606-791, Korea
}

Abstract : This paper aims to understand and analyze the mega-trends such as trends towards larger vessels due to an increasing trade volume, accordingly fewer port calls, strategic alliances and $M \& A$. Increasing degree of concentration through $M \& A$ activities in shipping industry results in a decreasing number of shipping firms with an increasing share in the world shipping capacity. But competition is strongly increasing on main trunk routes. Therefore, shipping concentration directly leads to further concentration of port traffic in fewer and larger ports with an increasing competition among neighboring ports.

Key words : Mega-trends, Shipping, Port logistics, Port development

\section{Introduction}

Globalization and consolidation are prevailing characteristics of the liner industry and port. An intense competitive environment, low freight rates, and the need for carriers to reduce their operation costs have led to joining some strategic alliance groups and, increasingly, mergers and acquisitions. Carriers have banded together in operating alliances with the objectives of improving asset utilization and providing shippers with extended route networks and greater service flexibility.

The most important recent trends that have affected shipping and port are containerization, telecommunication, globalization and deregulation. Concentration is another trend, which is expected to have a major impact. This refers to the increasing control in the hands of a small number of companies who hold an increasing market share(Hoffman 1998). Growth in trade is attributable to globalization and deregulation. These are the factors that have contributed to mergers, alliances and increases in vessel size and the increased use of transshipment facilities.

However, owing to mergers and acquisitions, there is an overall decline in the number of shipping lines in operation; it is also true that on most routes the number of companies has grown. As ship size increases and shipping line mergers and alliances continue, the economic advantage of reducing the number of port calls has become more pronounced, and this has resulted in a rapid rise in transshipment.

The share of transshipment within total demand is already high, and is forecast to continue rising, as major lines endeavor to serve the shipping market by as few direct calls as possible, thus increasing the hub-and ${ }^{-}$spoke distribution of containers. The increasing incidence of transshipment has had a massive effect on global container traffic volumes, and the average port transshipment incidence is about 48\% as measured across key hub ports worldwide. Given the underlying global trends, a positive growth outlook is anticipated for transshipment in Northeast Asia as it is in other regions. Consequently, new port developments, in order to create added values in port, with a strong transshipment orientation are expected.

Against this positive background of rapidly increasing traffic volumes and hub \& spoke strategy by major shipping lines, the rising incidence of transshipment, the physical constraints within established ports in terms of handling larger vessels and greater traffic flows has become more pronounced. Such factors have strengthened the development of new deep-water ports and transshipment terminals in the world. In this paper, the mega-trends in shipping and port is reviewed and their implications are studied.

\section{Major trends in shipping and port}

\subsection{Trends toward larger size and fewer port calls}

Sea transport constitutes one of the spheres particularly affected by modern technical progress: a continuous increase in the carrying capacity of ships and the exceptional intensity of new ship construction. Technology progress in shipping includes qualitative and quantitative progress. Both

* Corresponding Author : Hyun-Duk Kim, hyunduk@tit.ac.kr, 051)610-8487

** kmahn@mail.hhu.ac.kr, 051)410-4385 
progresses led to a similar result, an increase in the carrying capacity (Kim, 2003). Larger container ships are mainly built in order to achieve economies of scale (Cullinane and Khanna, 1999; Cullinane, et al., 1999). Due to the depth limits of container ports, fewer ports are able to directly serve the giant transoceanic vessels (Song, 2003). As shown in Table 1, the size of containerships become increasing very rapidly over time due to economies of scale.

Table 1 Development of containership

\begin{tabular}{|c|c|c|c|c|c|c|c|c|}
\hline & 1 st & 2nd & 3rd & 4 th & 5 th & 6 th & 7 th & 8 th \\
\hline $\begin{array}{c}\text { Length } \\
(\mathrm{m})\end{array}$ & 190 & 210 & $210 \sim 290$ & $270 \sim 300$ & $290-320$ & $305 \sim 310$ & $355 \sim 360$ & 365 \\
\hline $\begin{array}{c}\text { Speed } \\
\text { (Knot) }\end{array}$ & 16 & 23 & 23 & $24 \sim 25$ & 25 & 25 & 26.4 & - \\
\hline $\begin{array}{c}\text { Width } \\
\text { (m) }\end{array}$ & 27 & 27 & 32 & $37 \sim 41$ & $40 \sim 47$ & $38 \sim 40$ & 43 & 55 \\
\hline $\begin{array}{c}\text { Draft } \\
\text { (m) }\end{array}$ & 9 & 10 & 11.5 & $13 \sim 14$ & $13 \sim 14$ & $13.5 \sim 14$ & 14.5 & 15 \\
\hline (TEU) & 1,000 & 2,000 & 3,000 & 4,000 & 4,900 & 6,000 & 8,000 & 12,500 \\
\hline Period & 1960 s & 1970 s & 1980 s & 1984 & 1992 & 1996 & 2000 & 2005 \\
\hline Type & $\begin{array}{c}\text { Full } \\
\text { Container }\end{array}$ & Panamax & $\begin{array}{c}\text { Post } \\
\text { Panamax }\end{array}$ & $\begin{array}{c}\text { Post } \\
\text { Panamax }\end{array}$ & $\begin{array}{c}\text { Super } \\
\text { Panamax }\end{array}$ & $\begin{array}{c}\text { Super } \\
\text { Panamax }\end{array}$ & $\begin{array}{c}\text { Untra } \\
\text { Panamax }\end{array}$ \\
\hline
\end{tabular}

Source: Korea Maritime Institute(2004).

Table 2 shows developments of average ship size and of number of trading ship by major trunk route by Grand Alliance Group and TNWA over the period 1991-2000. As indicated in Table 2, average ship size and number of operation ship on trunk route increasing over time.

Concentration through M\&A between shipping lines result in fewer companies. Increasing degree of concentration does not mean diminishing competition. On a global scale, there are now fewer operators than in the past due to a variety of consolidation, but on most trunk trade routes the number of lines competing for cargo has actually increased as shown in Table 3 and 4 . Increasing vessels size require fewer port calls. It means that the number of ports served must be minimized. This tendency directly leads to further concentration of port traffic in fewer and larger ports increasing competition among some neighboring ports to be a transshipment port.

Table 2 Developments of average ship size and of number of trading ship

(Unit: TEU)

\begin{tabular}{|c|c|c|c|c|c|c|c|c|}
\hline Group & \multicolumn{3}{|c|}{ Grand Alliance Group } & \multicolumn{4}{c|}{ TNWA } \\
\hline Route & North America & \multicolumn{2}{c|}{ Europe } & \multicolumn{2}{c|}{ North America } & \multicolumn{2}{c|}{ Europe } \\
\hline Ship & $\begin{array}{c}\text { No. } \\
\text { Ship }\end{array}$ & $\begin{array}{c}\text { Average } \\
\text { Ship } \\
\text { Size }\end{array}$ & $\begin{array}{c}\text { No. } \\
\text { of } \\
\text { Ship }\end{array}$ & $\begin{array}{c}\text { Average } \\
\text { Ship } \\
\text { Size }\end{array}$ & $\begin{array}{c}\text { No. } \\
\text { of } \\
\text { Ship }\end{array}$ & $\begin{array}{c}\text { Average } \\
\text { Ship } \\
\text { Size }\end{array}$ & $\begin{array}{c}\text { No. } \\
\text { of } \\
\text { Ship }\end{array}$ & $\begin{array}{c}\text { Average } \\
\text { Ship } \\
\text { Size }\end{array}$ \\
\hline 1991 & 34 & 2,553 & 27 & 1,791 & 26 & 2,500 & 27 & 2,791 \\
\hline 1994 & 40 & 2,372 & 26 & 3,358 & 39 & 2,754 & 26 & 3,591 \\
\hline 1997 & 35 & 2,974 & 34 & 4,315 & 41 & 3,603 & 32 & 3,861 \\
\hline 2000 & 50 & 4,062 & 46 & 4,231 & 49 & 3,799 & 32 & 4,182 \\
\hline
\end{tabular}

Source: Containerization International Yearbook, Various issues.
Table 3 Trend of number of calling in Asian port by New World Alliance Group (TNWA)

\begin{tabular}{|c|c|c|c|c|c|c|c|c|c|}
\hline & \multirow{2}{*}{ Route } & \multicolumn{4}{|c|}{$\begin{array}{l}\text { North America } \\
\text { Route }\end{array}$} & \multicolumn{4}{|c|}{ Europe Route } \\
\hline & & 1993 & 1996 & 1999 & 2003 & 1993 & 1996 & 1999 & 2003 \\
\hline \multirow{2}{*}{$\mathrm{APL}$} & $\begin{array}{l}\text { No. of Direct } \\
\text { Calling }\end{array}$ & 9 & 14 & 16 & 20 & 0 & 12 & 16 & 17 \\
\hline & $\begin{array}{l}\text { Total No. of } \\
\text { Calling }\end{array}$ & 21 & 27 & 46 & 60 & 0 & 16 & 26 & 25 \\
\hline \multirow{2}{*}{ HMM } & $\begin{array}{l}\text { No. of Direct } \\
\text { Calling }\end{array}$ & 10 & 11 & 16 & 20 & 0 & 9 & 16 & 14 \\
\hline & $\begin{array}{l}\text { Total No. of } \\
\text { Calling }\end{array}$ & 29 & 31 & 46 & 60 & 0 & 11 & 26 & 20 \\
\hline \multirow{2}{*}{ MOL } & $\begin{array}{l}\text { No. of Direct } \\
\text { Calling }\end{array}$ & 11 & 14 & 16 & 22 & 9 & 12 & 16 & 14 \\
\hline & $\begin{array}{l}\text { Total No. of } \\
\text { Calling }\end{array}$ & 47 & 27 & 46 & 73 & 21 & 24 & 26 & 20 \\
\hline
\end{tabular}

Source: Containerization International Yearbook, Various issues.

Table 4 Trend of number of calling in Asian port by Grand Alliance Group

\begin{tabular}{|c|c|c|c|c|c|c|c|c|c|}
\hline & \multirow{2}{*}{ Route } & \multicolumn{4}{|c|}{ North America Route } & \multicolumn{4}{|c|}{ Europe Route } \\
\hline & & 1993 & 1996 & 1999 & 2003 & 1993 & 1996 & 1999 & 2003 \\
\hline \multirow{2}{*}{ NYK } & No. of Direct Calling & 12 & 14 & 17 & 20 & 11 & 12 & 16 & 17 \\
\hline & Total No. of Calling & 34 & 35 & 51 & 62 & 20 & 27 & 36 & 40 \\
\hline \multirow{2}{*}{$\begin{array}{l}\text { Hapag } \\
\text { Lloyd }\end{array}$} & No. of Direct Calling & 12 & 14 & 15 & 19 & 7 & 12 & 14 & 16 \\
\hline & Total No. of Calling & 30 & 24 & 31 & 44 & 13 & 23 & 32 & 34 \\
\hline \multirow{2}{*}{$\begin{array}{c}\text { P\&O } \\
\text { Nedlloyd }\end{array}$} & No. of Direct Calling & 0 & 19 & 17 & 20 & 10 & 12 & 16 & 16 \\
\hline & Total No. of Calling & 0 & 44 & 44 & 61 & 22 & 23 & 47 & 43 \\
\hline \multirow{2}{*}{ MISC } & No. of Direct Calling & 0 & 0 & 15 & 19 & 8 & 12 & 14 & 16 \\
\hline & \begin{tabular}{|l|} 
Total No. of Calling \\
\end{tabular} & 0 & 0 & 31 & 44 & 15 & 16 & 32 & 34 \\
\hline \multirow{2}{*}{ OOL } & No. of Direct Calling & 9 & 14 & 15 & 19 & 6 & 12 & 14 & 16 \\
\hline & Total No. of Calling & 21 & 27 & 31 & 44 & 6 & 16 & 32 & 34 \\
\hline
\end{tabular}

Source: Containerization International Yearbook, Various issues.

\subsection{M\&A and strategic alliances}

The international liner shipping industry has been undergoing major structural changes caused by a number of factors. Liner companies have responded to these challenges by engaging in mergers and acquisitions and by forming global strategic alliances. Many of these organizational changes have reportedly been undertaken to achieve, among other things, economies of scale. However, there clearly exists tendency towards more consolidation. Mergers and acquisitions seem to dominate the contemporary transport scene. Mergers and acquisitions for the period 1999-2001 in liner shipping include Safmarine Contanier Line and Sea-Land Services merged into Maersk Line by AP Molle, that of American Ships by $\mathrm{Cp}$ Ships, the merger between P\&O Nedlloyd and Farrel Lines, Harrison Line, the 50\% shareholding of Grimaldi in Atlantic Container Line as shown in Table 5. However, the main objectives for alliance participation quoted range from strengthening cargo consolidation, spreading the financial risk of capital 
investment, achieving better vessel and container deployment to reduce costs and economies of scale in landslide operations, and improving geographical coverage by rationalizing call patters (Glasister \& Buckley, 1996; Ryoo and Thanopoulou, 1999).

The first generation alliance, the so-called Global Alliances was sep up in 1994 by APL, OOCL, MOL and Nedlloyd. The objective was to establish an integrated Europe-Far East service (Stopford, 1997). Over the period 1998-2000, just about all-global carriers were involved in global alliance. Of the top 10 shipping firms, only Evergreen and Mediterranean Shipping Company (MSC) remained independent operators at that time.

However, alliances among lines have continued to evolve. A series of cross-alliance, mergers and acquisitions have forced established groups to form the five newly alliances. First, other alliance, so-called United alliance group has been formed. Second, there was the reorganization of the two important global alliances, i.e. the Grand Alliance and the Global Alliance, due to the creation of P\&O Nedlloyd in January 1997 and the takeover of APL by NOL in April 1997 to rationalize activities, reduce costs, and create significant economies of scale. The Grand Alliance with the entrance of OOCL and MISC and the New World Alliance became operation in January 1998. In 1997, with the takeover of DSR-Senator by Hanjin Shipping Co., Ltd, there was another reorganization between the United Alliance group and $\mathrm{C}-\mathrm{K}-\mathrm{Y}$ Alliance group. Such a result created a new $\mathrm{CKYH}$ group including Hanjin(Senator), COSCO, K-Line and Yang Ming.

Table 5 Major liner industry consolidation, 1999-2001

\begin{tabular}{|c|c|c|}
\hline Year & Purchaser & Company Acquired \\
\hline 1999 & AP Moller & Safamarine Container Lines \\
\hline 1999 & P\&O Nedlloyd & Tasman Express Line \\
\hline 1999 & CSAV & Montemar SA Compannia Libra de \\
\hline 1999 & Hamburegacao \\
\hline 1999 & Delmas & Transroll, South Pacific Container Lined \\
\hline 1999 & AP Moller & OT Africa Line \\
\hline 1999 & Sea Consortium & Sea Med Link \\
\hline 2000 & CP Ships & American Ships \\
\hline 2000 & Hamburg Sud & $\begin{array}{c}\text { Crowley American Transport deepsea } \\
\text { US/South America Service only }\end{array}$ \\
\hline 2000 & Naviera Odiel & Compania Trasatiatica Espanola \\
\hline 2000 & CP Ships & Christensen Canadian Africa Lines \\
\hline 2000 & CSAV & Norasia Line \\
\hline 2000 & P\&O Nedlloyd & Farrel Lines, Harrison Line \\
\hline 2000 & Grimaldi & Atlantic Container Line-40\% \\
\hline 2000 & Mars(related to & Atlantic Container Line-10\% \\
\hline 2001 & GMA CGMaldi & Atlantic Container Line 50\% \\
\hline
\end{tabular}

Source: LSE(2004).
In May 2005, the first largest liner shipping company, A. P. Moller-Maersk Sealand, proclaimed a proposed acquisition of Royal P\&O Nedlloyd. The bid, cash offer of 57 Euro per share, valuing the company at some 2.3 bn Euro, was approved by the RPONL board and seems likely to continue to completion by the end of 2005. The major impact on the combination is as following; Firstly, the acquisition would mean that the world's leading container line, Maersk-Sealand, absorbing the third largest, thus creating a double the size of its nearest competitor, Mediterranean Shipping Company.

Second, this takeover is expected to create a combined owned and chartered container fleet currently 549 ships with a shipboard capacity of about $1.5 \mathrm{~m}$ teu, representing about $19 \%$ of the world container capacity. The two companies also have a combined order book of a further 138 ships of 730,158 teu some $21 \%$ of the total capacity on order. The size of the combined company and its resulting market shares are therefore not likely to cause any anti-trust or completion regulation concerns (Lloyd's Shipping Economist 2005).

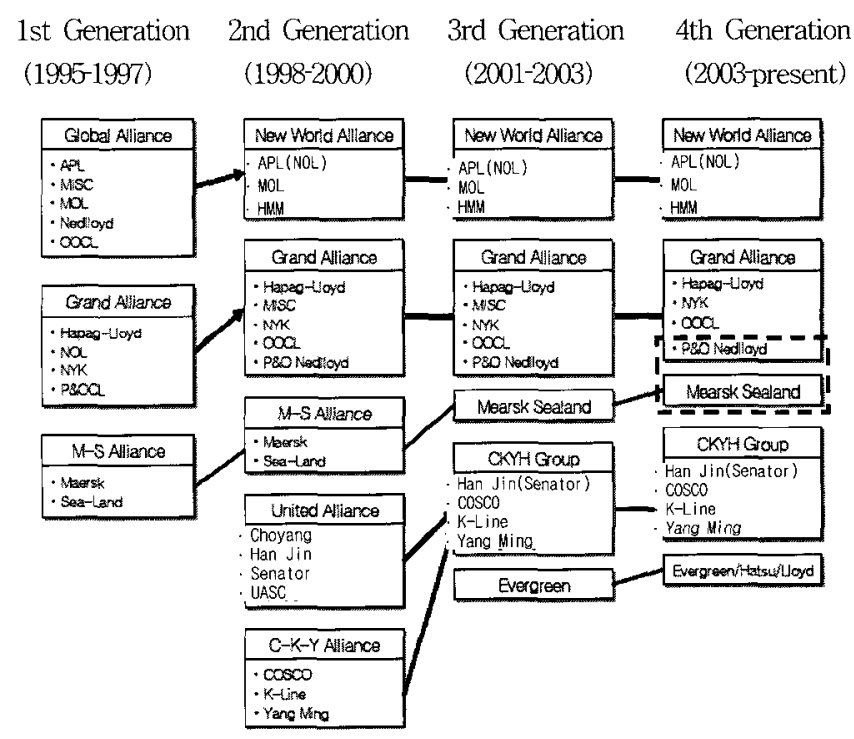

Fig. 1 Changing membership of Strategic Alliance Group

Table 6 Shipping fleet size after a proposed acquisition

\begin{tabular}{|c|c|c|c|c|c|c|}
\hline \multirow{2}{*}{} & \multicolumn{2}{|c|}{ Capacity } & \multicolumn{2}{c|}{$\begin{array}{c}\text { Order book } \\
(\sim 08)\end{array}$} & \multicolumn{2}{c|}{ Capacity in 2008 } \\
\cline { 2 - 7 } & $\begin{array}{c}\text { No. of } \\
\text { Ship }\end{array}$ & $\begin{array}{c}\text { TEU } \\
\left(000^{\prime}\right)\end{array}$ & $\begin{array}{c}\text { No. of } \\
\text { Ship }\end{array}$ & $\begin{array}{c}\text { TEU } \\
\left(000^{\prime}\right)\end{array}$ & $\begin{array}{c}\text { No. of } \\
\text { Ship }\end{array}$ & $\begin{array}{c}\text { TEU } \\
\left(000^{\prime}\right)\end{array}$ \\
\hline Maersk-Sealand & 387 & $1,036.6$ & 96 & 509.7 & 483 & $1,546.2$ \\
\hline P\&O Nedlloyd & 162 & 460.2 & 42 & 220.5 & 204 & 680.7 \\
\hline Total & 549 & $1,496.8$ & 138 & 730.2 & 687 & $2,226.9$ \\
\hline \% of the world & 14 & 19 & 19 & 21 & 15 & 20 \\
\hline
\end{tabular}

Source: Korea Maritime Institute and BRS-Alphaline (May 2005) Cellular Fleet \& Forecast, 
Table 7 Terminal operation list

\begin{tabular}{|c|c|c|c|c|}
\hline & Maersk* & $\begin{array}{c}\text { P\&O } \\
\text { Nedlloyd }\end{array}$ & $\begin{array}{c}\text { P\&O } \\
\text { Ports** }\end{array}$ & Total \\
\hline Europe & 6 & 2 & 6 & 14 \\
\hline $\begin{array}{c}\text { North } \\
\text { America }\end{array}$ & 14 & 2 & 8 & 24 \\
\hline Asia & 9 & - & 11 & 20 \\
\hline $\begin{array}{c}\text { South } \\
\text { America }\end{array}$ & 1 & - & 1 & 2 \\
\hline $\begin{array}{c}\text { Africa/Ocea } \\
\text { nia }\end{array}$ & 2 & - & 5 & 7 \\
\hline Total & 32 & 4 & 31 & 67 \\
\hline
\end{tabular}

Note: * Terminals operated by APM Terminal.

** Terminals owing share of P\&O Ports by P\&O Nedlloyd.

Thirdly, the takeover is expected to have an impact on the provision of global liner services. RPONL is a member of the Grand Alliance, providing coordinated services on the main trades. The takeover would mean withdrawing from that grouping and some other joint service that it operates. Other Grand Alliance members, three leading Asian carriers NYK, OOCL and MISC, together with German Hapag-Lloyd have to consider how they fill that gap. Such a situation could lead to a more substantial re-alignment of this and other global alliances of container services as well as some of the liner conferences that either or both belong to.

Finally, a further major impact is on the terminal operators all over the world as the two operators seek to consolidate their services and is expected to secure necessary terminals through strategic alliance with $\mathrm{P} \& \mathrm{O}$ group's subsidiary-P\&O Ports.

\section{Increasing degree of concentration in shipping and port}

The process of concentration in shipping - larger ships, mergers \& acquisitions, strategic alliances, has profound effects on port development. Larger ships and more transshipment require additional investments in port development. The use of larger ships and more transshipment directly leads to more port container movements and port throughput concentration in fewer and larger ports. The major port development plan in the world in order to be a regional hub port is summarized in Table 8 .

The international liner shipping industry is becoming more capital intensive, and more concentrated, than in the past, with each characteristic (capital intensity and concentration) factor the other in a circular pattern. In simple terms, economic and trade growth has driven increased demand for containerized shipping, which in turn has stimulated the construction of increasingly larger vessels to achieve economies of scale.
Table 8 Major port development plan in the world

\begin{tabular}{|c|c|c|c|c|c|c|}
\hline & Port & $\begin{array}{c}\text { Total area } \\
\left(000 \mathrm{~m}^{2}\right)\end{array}$ & $\begin{array}{l}\text { No. of } \\
\text { Berth }\end{array}$ & $\begin{array}{l}\text { Length } \\
\text { (M) }\end{array}$ & $\begin{array}{c}\text { Capacity } \\
\text { ('000 teu) }\end{array}$ & $\begin{array}{l}\text { Project } \\
\text { Period }\end{array}$ \\
\hline \multirow{3}{*}{ Hong Kong } & СТ 9 & 680 & 6 & 1,900 & 2,600 & $98 \sim 04$ \\
\hline & CT 10 & - & 4 & 1,280 & 1,600 & $\sim \sim^{\prime} 11$ \\
\hline & CT 11,12 & 800 & 8 & 2,560 & 3,200 & -11 \\
\hline \multirow{3}{*}{ Singapore } & Pair Panjang I & 1,270 & 8 & - & 2,400 & '93〜'07 \\
\hline & Pair Panjang II & 2,260 & 18 & - & 12,900 & $96-109$ \\
\hline & Pair Panjang II & Undecided & 23 & - & 1,600 & -27 \\
\hline \multirow{2}{*}{ Shanghai } & Waigaoqio $\mathrm{V}$ & - & 13 & - & - & '01 ' 11 \\
\hline & Yangsan & - & 52 & 21,200 & 15,000 & $.01 \sim 20$ \\
\hline \multirow{3}{*}{ Shenzen } & Chi-wan III & - & 4 & - & & \\
\hline & Shekou III & 830 & 5 & 1,750 & & $\sim^{\prime} 08$ \\
\hline & Yantian V & 1,020 & 6 & 1,828 & & \\
\hline \multirow{3}{*}{ Kaoshiung } & Phase I & - & 5 & - & 2,500 & ${ }^{\prime} 02 \sim \sim^{\prime} 08$ \\
\hline & Phase II & - & 4 & - & 2,000 & '04 '11 \\
\hline & Phase III & - & 14 & - & - & $' 11-' 20$ \\
\hline Busan & & - & 30 & 9,550 & 8,400 & $-^{\prime} 11$ \\
\hline
\end{tabular}

Sources: Korea Container Terminal Authority and Busan Port Authority(2005).

This movement to large vessels has, in turn, has led to the consolidation of shipping companies into large entities, with cargo movements by larger vessels focusing on fewer, major 'hub' ports, which can include consolidation and transshipment of containers from smaller ports / 'thin trade' (routes with lower cargo volumes).

The process of concentration in ports and shipping has gained force in recent years. Regular liner shipping companies are merging, alliances being formed and container ship sizes are increasing substantially as mentioned above. Private international port operators are acquiring a growing market share as a result of privatizations and the growing volume of trade. Hub ports are experiencing strong growth based on the increase in container transshipment.

Since the early 1990 s, the largest shipping lines which originally only operated on the east-west route (linking the United States, Europe and Asia) began to establish and strengthen global service networks encompassing practically all markets. This implies transshipment, the use of large container ships and cooperation through global alliances. These trends have led to acquisitions of small lines by major companies and to a series of mergers between lines that were already among the top 20 shipping companies in the world, as explained previously. Consolidation by a number of leading liner shipping companies will accelerate market concentration in the sector.

As shown in Table 9, a clear concentration is evidenced. The 20 carriers controlled just $26 \%$ of the world capacity in 1980. In 1988, the 20 biggest companies held $37.35 \%$ of the total world capacity, and $45.5 \%$ in 1996. In 1999, its share 
increased to $51.4 \%$. In 2002 , its share exceeds $60 \%$. The share of the top 10 carriers follows the similar pattern. This phenomenon confirms a clear concentration by a decreasing number of owners with an increasing share in the global capacity in liner shipping.

Table 9 Share in the global capacity by the top 10 and 20 shipping lines

\begin{tabular}{|c|c|c|c|c|c|}
\hline \multirow{2}{*}{ Year } & \multirow{2}{*}{$\begin{array}{c}\text { Total } \\
\text { Capacity }\end{array}$} & \multicolumn{2}{|c|}{ Top 20 Carriers } & \multicolumn{2}{c|}{ Top 10 Carriers } \\
\cline { 3 - 6 } & & Capacity & Share (\%) & Capacity & Share (\%) \\
\hline 1988 & 2.78 & 1.04 & 37.4 & 0.68 & 27.9 \\
\hline 1996 & 4.83 & 2.29 & 45.5 & 1.43 & 29.5 \\
\hline 1999 & 6.51 & 3.34 & 51.4 & 2.41 & 37.0 \\
\hline 2002 & 7.75 & 4.76 & 61.4 & 3.38 & 43.6 \\
\hline 2003 & 8.32 & 5.39 & 64.7 & 3.82 & 45.9 \\
\hline
\end{tabular}

Source: CI Yearbook, Various issues.

Table 10 represents growth trends of port throughput over the period 1999-2004. The port of Hong Kong was the world's largest container port in 2004, having handled an estimated 21,932,000 TEU due to the booming Pearl River of Delta and the stream of exports flooding out of the region's thousands of factories.

Table 10 The world top 10 ports

\begin{tabular}{|c|c|c|c|c|c|c|c|c|}
\hline & Port & 1999 & 2000 & 2001 & 2002 & 2003 & 2004 & $\begin{array}{c}\text { Growth } \\
\text { Rate }\end{array}$ \\
\hline \hline 1 & Hong Kong & 16,211 & 18,098 & 17,826 & 19,144 & 20,449 & 21,932 & 4.8 \\
\hline 2 & Singapore & 15,945 & 17,087 & 15,571 & 16,941 & 18,411 & 21,329 & 2.9 \\
\hline 3 & Shanghai & 4,216 & 5,613 & 6,334 & 8,620 & 11,280 & 14,567 & 21.8 \\
\hline 4 & Shenzen & 2,986 & 3,993 & 5,076 & 7,614 & 10,650 & 13,625 & 29.0 \\
\hline 5 & Pusan & 6,440 & 7,540 & 8,073 & 9,453 & 10,408 & 11,442 & 10.1 \\
\hline 6 & Kaohsiung & 6,985 & 7,426 & 7,541 & 8,493 & 8,840 & 9,714 & 4.8 \\
\hline 7 & Rotterdam & 6,342 & 6,275 & 6,096 & 6,506 & 7,144 & 8,281 & 2.4 \\
\hline 8 & L.A & 3,829 & 4,879 & 5,184 & 6,106 & 7,179 & 7,321 & 17.3 \\
\hline 9 & Hamburg & 3,738 & 4,248 & 4,689 & 5,374 & 6,138 & 7,100 & 10.4 \\
\hline 10 & Dubai & 2,845 & 3,058 & 3,502 & 4,194 & 5,152 & 6,429 & 12.6 \\
\hline
\end{tabular}

Source: Ports, CI Yearbook 2005 and $\mathrm{ci}^{-}$online.

Table 11 Growth trends of Northern Chinese ports

\begin{tabular}{|c|c|c|c|c|c|c|c|c|c|c|c|}
\hline & \multicolumn{10}{|c|}{ Throughput (000 TEU) } \\
\hline Year & 1990 & 1995 & 1996 & 1997 & 1998 & 1999 & 2000 & 2001 & 2002 & 2003 & 2004 \\
\hline Dalian & 13 & 37 & 42 & 45 & 53 & 65 & 84 & 122 & 135 & 163 & 251 \\
\hline Tianjin & 29 & 70 & 82 & 94 & 102 & 114 & 145 & 201 & 241 & 302 & 381 \\
\hline Qingdao & 14 & 60 & 81 & 103 & 121 & 125 & 191 & 264 & 341 & 424 & 514 \\
\hline Shanghai & 46 & 153 & 197 & 253 & 307 & 396 & 531 & 634 & 861 & 1,137 & 1,455 \\
\hline Total & 102 & 320 & 402 & 495 & 583 & 700 & 951 & 1,221 & 1,578 & 2,026 & 2,601 \\
\hline
\end{tabular}

Source: CI Yearbook and Northeast Asia Director's General Meeting (2nd) Progress Report on "Future Development of Sea Transportation Corridors in Northeast Asia", Sept. 2002, Seoul, Korea.
However, its nearby rival Shenzhen-comprising Chiwan, Shekou and Yantian-continues to grow at a much faster pace (annual growth rate $29 \%$ over the period), adding about 3 million TEU in 2004. Generally, there were few major movements up or down the 30 ranking, although Dubai ranked the top 10, displacing Antwerp, with a $24.8 \%$ rise to about 6,429 thousands TEU in 2004, compared to port throughputs amounting to 5,152 thousand TEU in 2003. Although statistical data including the top 30 container ports is not available in this table, the distinction of achieving the largest percentage gain in 2004 went to another Chinese port, Ningbo, as shown in Table 11, where TEU traffic grew by a staggering $44.5 \%$, resulting in it moving from 22 nd in 2003 to 17th position in 2004. And also Qingdao, Tianjin, Ghangzhou and Xiamen all recorded substantial growth, while Dalian seems destined to join the ranks of the top 30 for 2005 . According to ci-online data, TEU volumes at this northern Chinese port grew by an impressive $32.4 \%$ in 2004 , to 2,211,200 TEU, ensuring that Dalian rose from 44th to 34th position in ci-online's Container Traffic ranking.

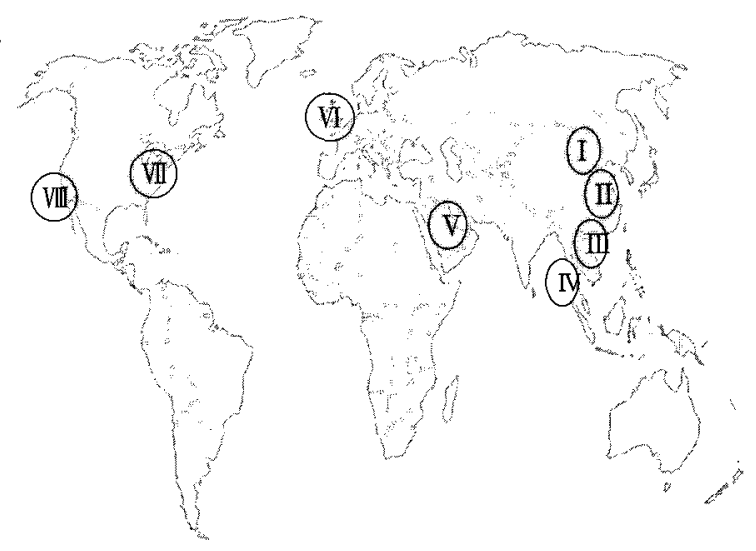

Note: I - Tian Jin, Qingdao, ПI- Busan, Shenzen, Shanghai, Tokyo, III- Ningbo, Kaohsiung, Hong Kong, IVSingapore, V-Dubai, VI -Hamburg, Antwerp, Rotterdam, VII - New York, New Jersey, VII - Los Angels, Long Beach.

Fig. 2 World top container ports in 2004

Fig. 2 represents the world top container ports in 2004. The top 10 ports are located in Asia and in particular, of the top 20 ports, 6 ports including Hong Kong are controlled by China. Intense and strong competition to preoccupy a regional hub port prevails in Northeast Asia. Mergers and alliances among large shipping lines are attributed to the transformation of some feeder ports into regional hub ports or vice versa (Song, 2003). As a consequence, ports compete locally as well as regionally against other ports, even long-distance, serving the same inland areas (Song, 2003; 
McCalla, 1999). Port competition can exist in several geographic dimensions: international vs. domestic, and regional vs. local. In the international dimension, ports in different countries can compete to handle the same business, because they serve similar hinterlands or can both serve as land bridge access points.

In the domestic dimension, ports within the same country compete with each other for business. This can occur between ports over great geographic distance. In regional competition, ports within a region that serve similar hinterlands and/or functions compete for the same cargoes. This can occur domestically or internationally. Finally, there is local competition, a primarily domestic phenomenon that occurs when ports that are close together compete with each other for the same business.

\section{Conclusions}

Mega-trends in shipping and port \& its implications are explained and analyzed in this paper. This paper aims to understand and analyze the mega-trends such as trends towards larger vessels due to an increasing trade volume, accordingly fewer port calls and strategic alliances and M\&A, port development plan in the world. Increasing degree of concentration through M\&A activities in the shipping industry results in a decreasing number of shipping firms with an increasing share in the world capacity. But competition is strongly increasing on main trunk routes. Shipping concentration directly leads to further concentration of port traffic in fewer and larger ports increasing competition among neighboring ports. The major ports, in particular, in Northeast Asia are trying to attract shipping lines and cargoes in order to preoccupy a regional hub port and transshipment terminal considering the rapid ever-changing shipping and port logistics.

In terms of pursuing a regional hub port, several questions are drawn from this paper. Which port will be a hub port and transshipment terminal in the future? Which factors will influence shipping line's decision-making? Which port will be a hub port in Northeast Asia where exists strong competition? Which factors in port are most important to attract a shipping line and cargoes? To what extent and degree concentration in shipping and port proceed?

In order to overcome some limitations to this paper, detailed comparative analysis or empirical studies have to be carried out. For empirical studies, major container ports' selection factors by major shipping lines are to be surveyed and questionnaired for establishing a generalized port choice model. Such a model contribute to establishing more reliable hub-port strategy and implementing customer-oriented strategy in Northeast Asia.

\section{References}

[1] Containerization International, Various Issues.

[2] Cullinance, K and Khannna, M. (1999) "Economies of scale in larger container ships", Journal of Transport Economics and Policy, Vol. 33, pp. 185-208.

[3] Cullinane, K, Khanna, M. and Song, D.-W.(1999), “How big is beautiful: Economies of Scale and the Optional Size of Containership", Proceedings of the International Association of Maritime Economists Conference, Haifax, Canada.

[4] Glaister, K. W. and Buckley, P. J.(1996), "Strategic Motives for International Alliance Formation", Journal of Management Studies, Vol. 33, pp. 301-332.

[5] Jan Hoffman(1998), "Concentration in Liner Shipping: Its Causes and Impacts for Port and Shipping Services in Developing Countries", pp. 1-30.

[6] Kim Hyun-Duk(2004), "Concentration and Centralization of Tonnage in Korean Shipping, Journal of Korean Navigation and Port Research", Vol. 28, pp. 121-127.

[7] Korea Maritime Institute(2004), Statistical Data.

[8] Korea Container Terminal Authority(2005), "Situation Analysis of Major Ports in the World".

[9] Lloyds's Shipping Economist, Various Issues.

[10] McCalla, R.(1999), "Global Change, Local Pain: Intermodal Seaport Terminals and their Service Areas", Journal of Transport Geography, Vol. 7, pp. 247-254.

[11] Ryoo Dong-Keun and Thanopoulou, H. A.(1999), "Liner Alliances in the Globalization Era: a Strategic Tool for Asian Container Carreirs", Maritime Policy and Management, Vol. 26, pp. 349-367.

[12] Song D-W(2004), "Port Co-opetition in Concept and Practice", Maritime Policy and Management, Vol. 30, pp. 29-44.

[13] Stopford, M.(1997), "Maritime Economics", 2nd Edition, pp. $137-138$.

[14] UNCTAD(2004), "Review of Maritime Transport".

Received 12 September 2005

Accepted 29 September 2005 